혈관기질분획의 정맥 주사 후 발생한 뇌경색

서진영 이주헌 송홍기 배종석 김예림

한림대학교 의과대학 강동성심병원 신경과

\title{
Embolic Infarction Presented after Intravenous Injection of Stromal Vascular Fraction
}

Jin Young Seo, Ju-Hun Lee, Hong-Ki Song, Jong Seok Bae, Yerim Kim

Department of Neurology, Kangdong Sacred Heart Hospital, Hallym University College of Medicine, Seoul, Korea

The popularity of adipose-derived stem cell therapy has increased, and only few adverse events are reported. We report a rare complication of cerebral infarction associated with stromal vascular fraction. A 89-year-old female was admitted with sudden right facial palsy and dysarthria just after intravenous injection of stromal vascular fraction. Her brain imaging revealed multiple hyperintensities on right cerebellum, both occipital lobes, left parietal lobe, and both frontal lobes. Serologic work-up for coagulopathy and cardiologic evaluation were unremarkable. We suggest that intravenous injection of stromal vascular fraction might be associated with multiple embolic cerebral infarction.

J Neurosonol Neuroimag 201S;10(2):1\$1-1\$4

Key Words: Stem cells; Stromal cells; Embolism; Stroke
Received: November 25, 2018

Revised: December 7, 2018

Accepted: December 8, 2018

Address for correspondence: Yerim Kim

Department of Neurology, Kangdong Sacred Heart Hospital, Hallym University College of Medicine, 150 Seongan-ro, Gangdong-gu, Seoul 05355, Korea

Tel: $+82-2-2224-2206$

Fax: +82-2-2224-2339

E-mail: brainyrk@hallym.ac.kr
지방 조직에서 유래한 줄기세포(adipose-derived stem cell, $\mathrm{ADSC}$ )는 다양한 질환에 사용될 수 있는 새로운 치료법 으로 부상하고 있다. 특히 지방조직에서 collagenase 등의 효 소를 이용하여 분리된 혈관기질분획(stromal vascular fraction, SVF)은 관절강내 주사, 정맥내 주사, 디스크내 주사 등 다양한 경로로 인체내 주입되며 그 안정성과 치료 효과에 대 한 몇몇 연구들이 알려져 있다. ${ }^{1,2}$ 하지만 현재 SVF와 관련된 많은 연구들은 전임상 시험단계이며 사람을 대상으로 한 연구 는 제한적이다. ${ }^{1}$ 아직 $\mathrm{SVF}$ 의 부작용에 대한 보고는 잘 알려져 있지 않으며 두통, 주입 부위의 통증, 감염 등 심각하지 않은 부작용에 대한 언급이 대부분이다. ${ }^{2}$ 그러나 SVF의 정맥내 주 사 이후 발생한 뇌경색의 증례는 확인할 수 없었다. 저자들은 SVF 정맥내 주사 직후 뇌경색이 유발된 드문 증례를 경험하였 기에 문헌고찰과 함께 보고하는 바이다.

\section{증 례}

89세 여자 환자가 내원 당일 갑자기 발생한 우측 얼굴 마비 및 구음장애를 주소로 내원하였다. 환자는 지역 병원에서 건강 보조를 목적으로 2 시간 동안 줄기세포 정맥주사를 다 맞은 직 후 증상이 발생하여 본원으로 이송되었다. 과거력상 고혈압 병 력으로 고혈압약제를 복용 중이었으며 양쪽 무릎에 고관절염 이 있어 지팡이 보행이 가능한 상태였다. 이외에 가족력 및 다 른 특이 사항은 없었다.

내원 당시 혈압은 $155 / 80 \mathrm{mmHg}$, 맥박수 83 회/분, 체온은 $36.9^{\circ} \mathrm{C}$, 호흡수는 20 회/분이었다. 신경학적 검사상 의식은 명 료하였고 신경학적 검사에서 우측 중추성 안면신경 마비 외 다 른 특이 소견은 없었다. 고위 대뇌 피질기능, 운동 및 감각 신 경계 기능, 소뇌기능에는 이상 소견이 관찰되지 않았다. 내원 당일에 시행한 뇌 혈관 computed tomography 상에서는 주 요 동맥의 협착 및 폐쇄 소견이 보이지 않았다.

일반혈액검사에서 특이 소견은 없었으며 일반화학검사에 서 lipase $13 \mathrm{U} / \mathrm{L}$, protein, total $6.0 \mathrm{~g} / \mathrm{dL}$, albumin $3.6 \mathrm{~g} / \mathrm{dL}$ 
로 약간 감소된 것 외에는 정상이었다. 혈액응고장애에 대 한 검사로 시행한 prothrombine time/activated partial thromboplastine time 모두 정상 범위 내에 있었으며 protein $\mathrm{C} / \mathrm{S}$, lupus anticoagulant, fibrin degradation product, fibrinogen, antithrombin III 또한 모두 정상이었 으나 D-dimer는 $3.32 \mathrm{mg} / \mathrm{L}$ fibrinogen equivalent units $(\mathrm{FEU})$ 로 증가되어 있었다. 추가로 시행한 면역혈청검사에서 fluorescent antinuclear antibody (FANA) titer $>1: 1,280$ 으로 양성 소견이 나왔으며 complement, C3가 $80 \mathrm{mg} / \mathrm{dL}$ 로 약간 감소된 것 외에는 complement, $\mathrm{C} 4$, anti-cardiolipin antibody, anti-beta2 glucose-6-phosphate isomerase antibody, $\mathrm{p}$-anti-neutrophil cytoplasmic antibody (ANCA), c-ANCA, rheumatoid factor 모두 특이 소견은 없 었다. 심전도, 72시간 Holter monitoring, 경흉부심장초음파 (transthoracic echocardiography)검사 상에서는 심인성 색 전증을 의심할 만한 소견은 전혀 관찰되지 않았다. 내원 다음 날 시행한 뇌 자기공명영상에서 우측 소뇌, 좌측 두정엽, 양측 전두엽, 후두엽 피질에 다수의 작은 급성 뇌경색 소견이 관찰 되었으며(Fig. 1) 자기공명 뇌혈관촬영 상에서는 주요 대뇌 동 맥 및 경동맥에 협착이나 폐쇄 소견은 보이지 않았다(Fig. 2).
환자는 입원 2 일째부터 우측 안면마비 및 구음장애 증상이 호 전되었으며, 입원 7일 후 퇴원하였다.

\section{고 찰}

줄기세포(stem cell)는 적절한 신호에 의해서 다양한 조직 으로 분화할 수 있는 능력을 가진 전구세포로서 배아줄기세포 (embryonic stem cell)와 성체줄기세포(adult stem cell)로 분류된다. ${ }^{1}$ 성체줄기세포는 배아줄기세포의 윤리적 문제에 대 한 한계점을 극복할 수 있으며 다양한 세포로 분화할 수 있는 다잠재성을 가지고 있다. 이에 성체줄기세포는 난치병에 대하 여 새로운 치료법으로 부상하고 있으며, 지금까지는 다분화 능 력을 가진 중간엽 줄기세포(mesenchymal stem cell)를 얻기 위하여 주로 골수를 이용한 연구들이 많이 이루어졌다. 그러나 골수에서의 충분한 양의 세포 획득을 위해서는 환자의 고통과 부담이 수반되어야 한다는 단점이 있다. 지방조직은 많은 양의 조직 채취가 용이하며 다분화 능력을 가진 성체줄기세포를 포 함하고 있다. 이를 $\mathrm{ADSC}$ 라 지칭하며 최근에는 이에 대한 연 구들이 나오고 있다. ${ }^{3,4} \mathrm{SVF}$ 는 지방조직에서 성숙 지방세포,
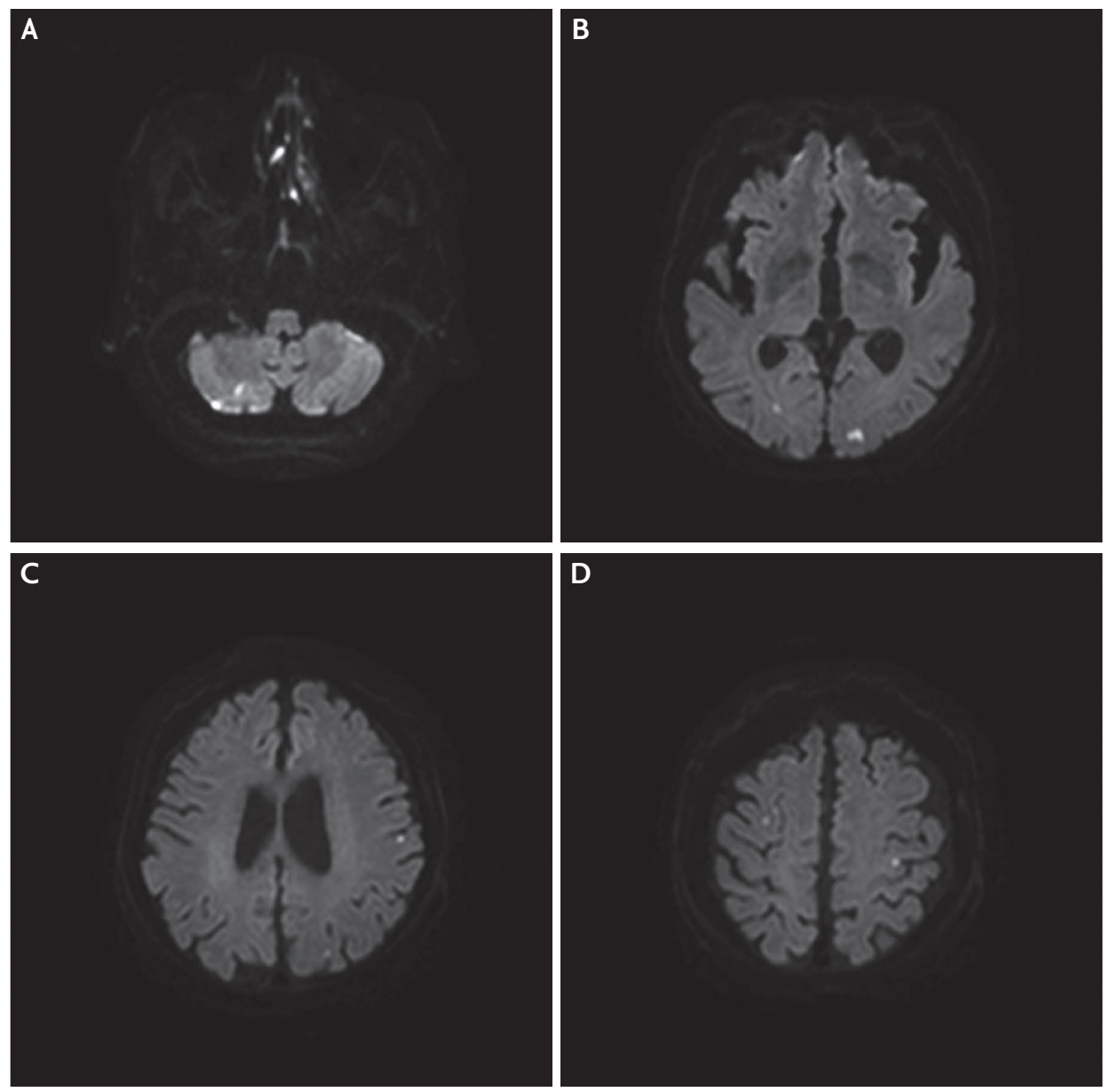

FIG. 1. Brain diffusion magnetic resonance imaging shows high signal intensity on (A) right cerebellum, $(B)$ both occipital lobes, (C) left parietal lobe, and (D) both frontal lobes. 

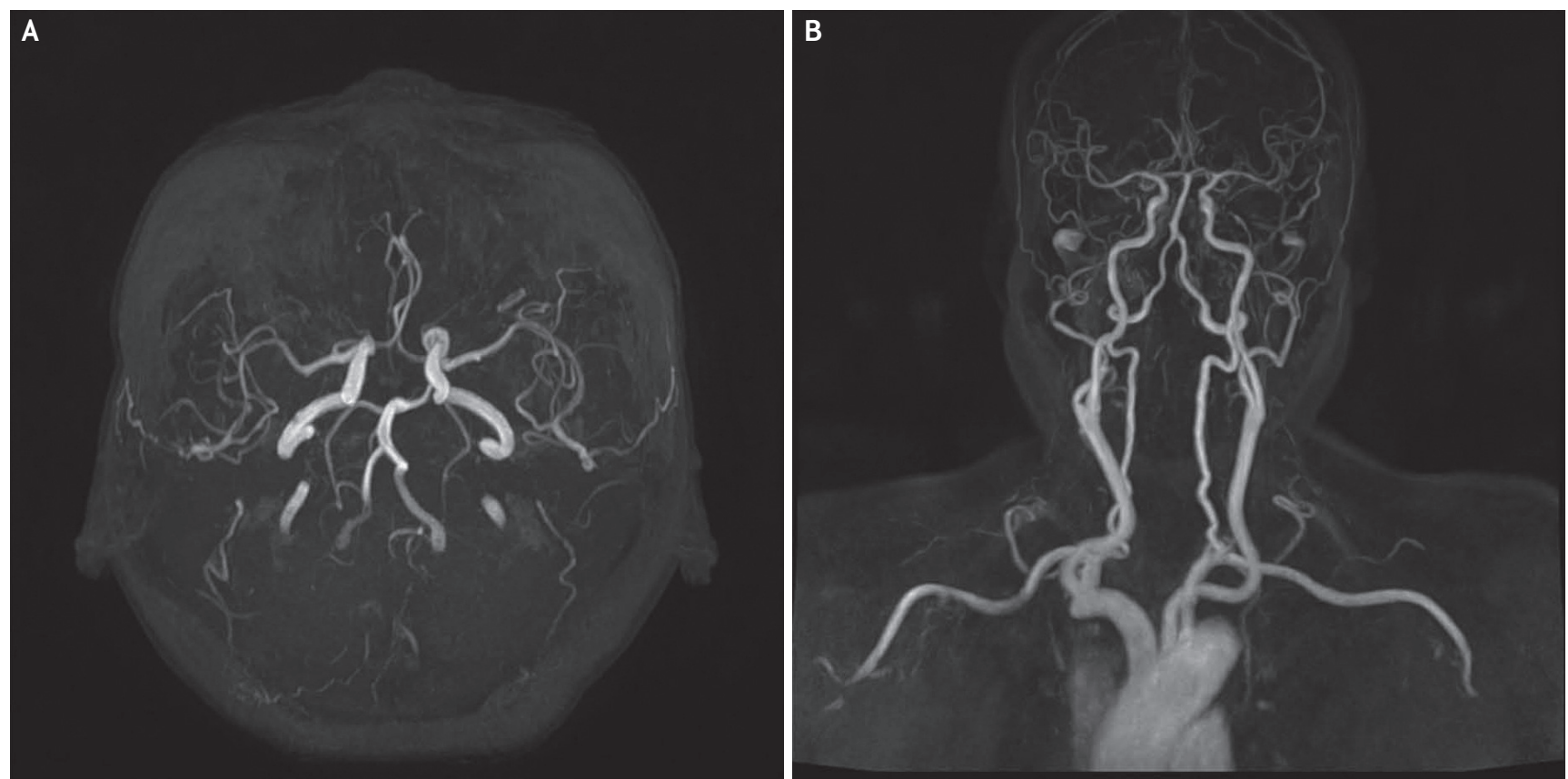

Fig. 2. Brain magnetic resonance angiography shows no significant arterial stenosis in (A) intracranial vessels and (B) neck vessels.

적혈구 등을 제거하여 $\mathrm{ADSC}$ 와 성장인자(growth factor)들을 취하는 방법이지만 여기에는 지방전구세포 등의 지방세포의 각 분화단계에 해당하는 여러 가지 물질들이 포함되어 있다. ${ }^{1-4}$

최근 새로운 치료법으로서 SVF가 부각되고 있지만 그 안정 성에 대해서는 아직 논란의 여지가 있다. 다양한 주입 경로를 통하여 다양한 질환에 치료제로 사용될 수 있는 만큼 일으킬 수 있는 부작용 또한 다양하게 나타난다. 두통, 지방 흡입 부 위 혹은 줄기세포 주입 부위의 통증 등의 경한 부작용이 대부 분이지만 혈전색전증 등과 같은 중한 부작용과 관련된 증례 및 연구들도 보고되고 있다. ${ }^{2,5-7}$ Toyserkani 등 ${ }^{5}$ 은 $\mathrm{ADSC}$ 주입 후 발생할 수 있는 다양한 합병증에 대하여 검토하였고, 자가 $\mathrm{SVF}$ 심근내 주입 후 발생한 심근경색 및 동종 $\mathrm{ADSC}$ 정맥주 사 8일 후 발생한 열공뇌경색을 보고하였다.

본 환자는 지역병원에서 건강증진 목적으로 자가 지방세 포를 흡입하여 추출한 SVF를 정맥주사로 맞았다. 세포 수는 200 만-250만 정도였으며 생리식염수 $200 \mathrm{~mL}$ 와 혼합하여 1-2시간 동안 약 $25 \mathrm{gtt}$ 로 주입하였다. SVF 정맥주사와 뇌경 색의 직접적인 연관성을 입증하기는 어려우나, 환자는 주입 직 후 안면마비 증상이 발생하였으며 뇌 자기공명영상에서 색전 에 의한 뇌경색이 의심되었다. 과거력으로 고혈압만 있었고, 심전도, 72 시간 Holter monitoring, 경흉부심장초음파검사 상에서는 특이 소견이 없었기에 심인성 색전 외 다른 원인에 의한 색전을 고려하였다.

혈액검사 결과에서 D-dimer $3.32 \mathrm{mg} / \mathrm{L} \mathrm{FEU로} \mathrm{상승,}$ FANA titer $>1: 1,280$ 으로 양성이 나온 것 외에는 특이점이 없었다. FANA는 세포핵 내에 존재하는 다양한 항원군에 대
한 항체들의 총칭인 항핵항체(antinuclear antibody)를 면 역형광법(immunofluorescence)으로 검사한 것을 의미한다. FANA의 염색패턴에 따른 분류에는 다양한 종류가 있으며 본 환자의 경우 speckled pattern으로 전신홍반성루프스(systemic lupus erythematosus), 피부경화증(scleroderma), 쇼그렌증후군 등의 자가면역질환을 생각해 볼 수 있다. 그러 나 FANA의 역가가 의미 있게 상승하였다 할지라도 환자가 관 련 증상이 없고 고령임을 고려하였을 때 위양성의 가능성이 높 다. ${ }^{8}$

결국 환자에게 색전증 뇌경색을 발생시킨 원인으로 정맥주 사를 통한 SVF 주입을 고려할 수 있으며 세 가지 기전으로 설 명해볼 수 있다. 첫째, $\mathrm{ADSC}$ 를 전신적으로 주입시 혈전색전 증의 발생이 가능하다는 연구 결과들이 이를 뒷받침한다. ${ }^{5}$ 둘 째, SVF는 이종세포 혼합물(heterogenous cell mixture)로 여기에는 지방세포의 각 분화단계에 따른 여러 성분들 및 적혈 구 등의 성숙세포도 있을 수 있다. ${ }^{5}$ 미미하게 존재하는 성숙지 방세포나 그 전 단계의 미분화된 세포들이 성숙지방세포로 분 화되면서 지방색전증을 일으킬 수 있으며 이는 뇌경색의 원인 이 되기도 한다. ${ }^{9}$ 셋째, 어떤 물질이든 정맥주사로 주입된 것 은 전신순환을 통하여 뇌동맥에 도달할 수 있고 색전의 원인이 될 수 있다. 가령 피부에 주입된 것이라 하더라도 주사의 끝이 혈관에 닿아 있다면 동정맥 문합(arteriovenous anastomosis)에 의하여 뇌동맥에 도달할 가능성이 있다. ${ }^{10}$

본 증례에서는 SVF 주입 직후 증상이 발생되어 시간적 인과 관계에 따라 SVF 주입에 따른 색전 형성에 의한 뇌경색일 가 능성이 높다. 그러나 고령이더라도 더 명확한 감별을 위하여 
경식도심장초음파(transesophageal ecochardiography)를 추가적으로 진행하지 못한 것이 아쉽다. 또한 암에 대한 과거 력 및 가족력이 없더라도 D-dimer가 증가된 소견을 고려하여 암에 대한 검사들을 시행하지 못한 점도 아쉬움으로 남는다. 더불어 주입된 SVF의 성분 분석이 시행되지 않았다는 점도 이 증례의 제한점이라 생각된다.

그러나 SVF에 대한 관심과 사용 범위가 커짐에 따라 발생 할 수 있는 부작용에 대해서도 충분한 논의가 필요하기에 저자 는 이를 문헌고찰과 함께 의미 있는 증례로서 보고한다. 결론 적으로 SVF를 뇌경색 발생의 한 위험요소로 단정할 수는 없으 나 난치성 질환의 치료제로서가 아닌 단순 건강증진을 목적으 로 무분별하게 사용하는 것은 주의가 필요할 것으로 사료된다.

\section{Acknowledgments}

This work was supported by Basic Science Research Program through the National Research Foundation of Korea (NRF) funded by the Ministry of Science and ICT (NRF-2018R1C1B5086320).

\section{REFERENCES}

1. Nguyen A, Guo J, Banyard DA, Fadavi D, Toranto JD, Wirth GA, et al. Stromal vascular fraction: a regenerative reality? Part 1: current concepts and review of the literature. J Plast Reconstr Aesthet Surg. 2016;69:170-179.

2. Comella K, Parlo M, Daly R, Depasquale V, Edgerton E, Mallory P, et al. Safety analysis of autologous stem cell therapy in a variety of degenerative diseases and injuries using the stromal vascular fraction. J Clin Med Res. 2017;9:935-942.
3. Kim MK, Park YS, Park HS, Choi JM, Kim WJ, Park SE, et al. Isolation of density enrichment fraction of adipose-derived stem cells from stromal vascular fraction by gradient centrifugation method. Endocrinol Metab. 2010;25:103-109.

4. Zuk PA, Zhu M, Ashjian P, De Ugarte DA, Huang JI, Mizuno $\mathrm{H}$, et al. Human adipose tissue is a source of multipotent stem cells. Mol Biol Cell. 2002;13:4279-4295.

5. Toyserkani NM, Jørgensen MG, Tabatabaeifar S, Jensen CH, Sheikh SP, Sorensen JA. Concise review: a safety assessment of adipose-derived cell therapy in clinical trials: a systematic review of reported adverse events. Stem Cells Transl Med. 2017;6:1786-1794.

6. Furlani D, Ugurlucan M, Ong L, Beiback K, Pittermann E, Westien I, et al. Is the intravascular administration of mesenchymal stem cells safe? Mesenchymal stem cells and intravital microscopy. Microvasc Res. 2009;77:370-376.

7. Tatsumi K, Ohashi K, Matsubara Y, Kohori A, Ohno T, Kakidachi $\mathrm{H}$, et al. Tissue factor triggers procoagulation in transplanted mesenchymal stem cells leading to thromboembolism. Biochem Biophys Res Commun. 2013;431:203-209.

8. Lee SH, Lee DR, Lee DJ, Kim KM, Park SB, Kim BT. Interpretation of tests for autoimmune disease. Korean J Fam Pract. 2012;2:221-232.

9. Mijalski C, Lovett A, Mahajan R, Sundararajan S, Silverman $S$, Feske S. Cerebral fat embolism: a case of rapid-onset coma. Stroke. 2015;46:e251-e253.

10. Lee WS, Yoon WT, Choi YJ, Park SP. Multiple cerebral infarction with neurological symptoms and ophthalmic artery occlusion after filler injection. J Korean Ophthalmol Soc. 2015;56:285-290. 